\begin{tabular}{|c|c|c|}
\hline & $\begin{array}{c}\text { Bioeduca: Journal of Biology Education } \\
\text { http://journal.walisongo.ac.id/index.php/bioeduca } \\
\text { ISSN 2714-8009 (print), 2715-7490 (online) }\end{array}$ & BIOEDUCA \\
\hline WALISONGO & $\begin{array}{c}\text { Volume 2, Nomor } 1 \text {, Tahun } 2020 \\
\text { Hal. } 40-51\end{array}$ & \\
\hline
\end{tabular}

\title{
Pengembangan Media Pembelajaran Ular Tangga Bercerita Berbasis Pendidikan Karakter Untuk Meningkatkan Kemampuan Berpikir Kritis Siswa Kelas X Pada Materi Ekosistem
}

\author{
Inayatus Solekhah ${ }^{1^{*}}$, Nur Khasanah ${ }^{2}$, Anif Rizqianti Hariz ${ }^{3}$ \\ 1,2,3Pendidikan Biologi, Universitas Islam Negeri Walisongo Semarang \\ *Email: Inayatussolekhah22320@gmail.com
}

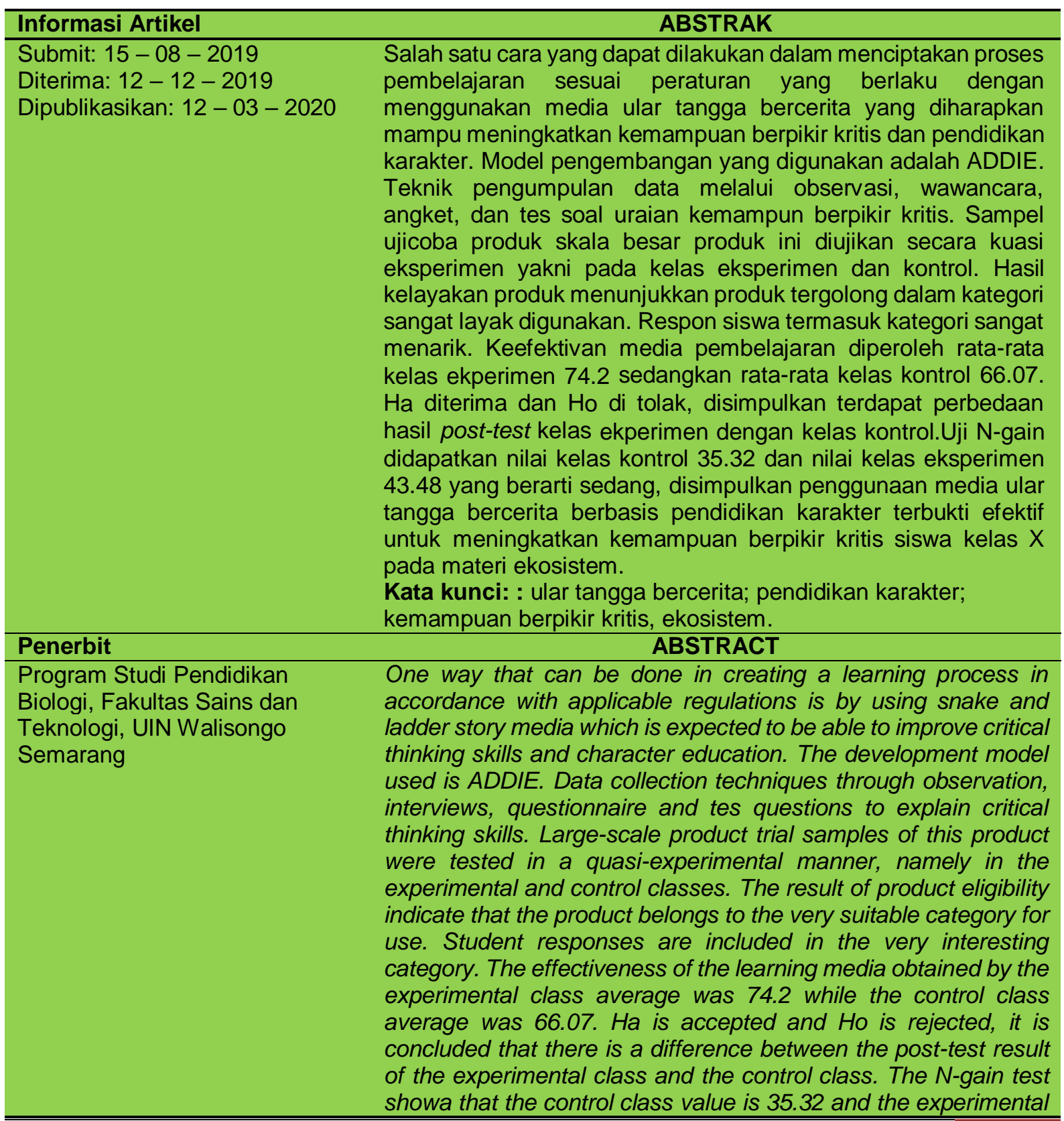

Inayatus Solekhah et al. - Pengembangan Media Pembelajaran Ular Tangga Bercerita Berbasis Pendidikan Karakter Untuk Meningkatkan Kemampuan Berpikir Kritis Siswa 
class value is 43.48 which means moderate, it is concluded that the use of snake and ladder media based on character education is proven effective improve critical thinking skills of class $X$ students on ecosystem material.

Keywords: ecosystem; critical thinking skills; character building; snake and ladder tells stories.

Copyright (C2020, Bioeduca: Journal of Biology Education

\section{PENDAHULUAN}

Proses pembelajaran merupakan hal yang penting dalam dunia pendidikan. Pentingnya pelaksanaan proses pembelajaran menjadikan Negara Indonesia memiliki panduan dalam pelaksanaannya. Peraturan Pemerintah No. 19 Tahun 2005 tentang Standar Nasional Pendidikan (SNP) pada pasal 19, menyebutkan bahwa proses pembelajaran pada satuan pendidikan diselenggarakan secara interaktif, inspiratif, menyenangkan, menantang, dan memotivasi peserta didik untuk berpartisipasi aktif dalam peningkatan potensi sesuai dengan bakat dan minat peserta didik untuk menunjang perkembangan fisik serta psikologisnya.

Proses pembelajaran akan berlangsung jika terdapat 3 komponen yaitu: guru (pendidik), siswa (peserta didik), dan fasilitas (media dan sumber belajar). Media pembelajaran diartikan sebagai suatu benda yang dapat diindrai, baik dengan penglihatan maupun pendengaran, yang digunakan sebagai alat penghubung (media komunikasi) dalam proses interaksi belajar mengajar untuk meningkatkan efektivitas hasil belajar siswa (Daradjat dalam Ramli, 2015: 132). Media pembelajaran digunakan untuk menciptakan pembelajaran yang menyenangkan, inspiratif, dan mudah dipahami, sehingga mampu meningkatkan kemampuan berpikir kritis.

Sejumlah ahli mendefinisikan kemampuan berpikir kritis adalah proses menemukan pengetahuan yang aktif melalui keterampilan dengan membuat pengertian atau konsep, mengaplikasikan, menganalisis, membuat sistesis, dan mengevaluasi suatu informasi melalui kegiatan observasi, pengalaman, pemikiran, pertimbangan, dan komunikasi yang akan membimbing dalam menentukan sikap dan tindakan (Zubaidah, 2010: 2). Kemampuan berpikir kritis merupakan tuntutan yang dirumuskan dalam Standar Kompetensi Lulusan (SKL) pada setiap mata pelajaran, khususnya mata pelajaran Biologi, tertuang dalam Standar Isi (SI) yang bertujuan agar peserta didik memiliki kemampuan dalam memupuk sikap ilmiah yaitu: jujur, objektif, terbuka, ulet, kritis, dan dapat bekerja sama dengan orang lain (BSNP,2006: 451).Uraian tersebut mengindikasikan pentingnya mengembangkan kemampuan berpikir kritis serta perlunya pengimplementasian nilai karakter di lingkungan sekolah dalam bentuk pendidikan karakter.

Pentingnya pendidikan karakter berfungsi mengembangkan potensi peserta didik untuk menjadi pribadi dengan perilaku yang baik. memperkuat dunia pendidikan untuk bertanggung jawab dalam pengembangan potensi peserta didik yang lebih bermartabat. menyaring budaya bangsa sendiri dan budaya bangsa lain yang tidak sesuai dengan nilai-nilai budaya dan karakter bangsa yang bermartabat (Kementerian Pendidikan Nasional, 2010: 7). Pentingnya mengembangkan kemampuan berpikir kritis dan pendidikan karakter sehingga proses pembelajaran yang dikembangkan

Inayatus Solekhah et al. - Pengembangan Media Pembelajaran Ular Tangga Bercerita

Berbasis Pendidikan Karakter Untuk Meningkatkan Kemampuan Berpikir Kritis Siswa 
guru harus dapat mengembangkan kedua hal tersebut serta harus dapat memenuhi peraturan yang berlaku.

Hasil observasi dan wawancara mengenai proses pembelajaran biologi yang dilakukan kepada Guru Biologi kelas X MA Hidayatul Mubtadi'in, ibu Ikhwatul Hanum, S.Pd. pada tanggal 21 Desember 2018 menunjukkan bahwa implementasi kurikulum yang berlaku tidak diterapkan secara masif, dikarenakan adanya berbagai kendala seperti: Guru sebagai mediator bukan sebagai fasilitator, kurangnya inovasi dan variasi dalam menggunakan media pembelajaran (media yang digunakan seringkali powerpoint, video, dan LKS). Selain itu, penggunaan metode pembelajaran yang cenderung monoton (seperti: ceramah, diskusi, dan tanya jawab), sehingga berakibat pada minimnya antusias dan partisipasi peserta dalam pembelajaran seperti: siswa asyik dengan kegiatannya sendiri, siswa kurang merespon pertanyaan dan informasi yang disampaikan guru, siswa cenderung bosan dengan materi yang disampaikan, sehingga berakibat pada pencapaian hasil belajar siswa kelas X MA Hidayatul Mubtadi'in telah mencapai $65 \%$ dari nilai KKM yang ditetapkan yakni 70 .

Solusi yang dapat dilakukan untuk mengatasi permasalah proses pembelajaran tersebut adalah dengan menciptakan pembelajaran yang menyenangkan dilakukan dengan media permainan. Media permainan atau permainan edukatif merupakan kegiatan/aktivitas bermain yang di desain atau untuk menstimulasi aspek perkembangan anak dan meningkatkan kreativitas peserta didik(Wartini \& Muhammad, 2015: 110). Salah satu media permainan yang dijadikan sebagai alat bantu pembelajaran yaitu: ular tangga bercerita. Permainan ular tangga merupakan permainan tradisional yang biasa dimainkan oleh anak-anak. Konsep permainan ular tangga yaitu: permainan dimainkan 2 orang/lebih dengan melempar dadu yang terdiri dari beberapa kotak, didalamnya terdapat gambar tangga dan ular. Apabila dalam permainan mendapatkan tangga berarti naik sesuai tangga tersebut dan apabila mendapatkan ular maka pemain harus turun sesuai jalur ular tersebut. Pemain dikatakan menang apabila tiba di kotak finish pertama (Afandi, 2015: 80). Permainan ular tangga bercerita juga melatih siswa untuk meningkatkan kemampuan berpikir kritis dan menerapkan nilai karakter.

Sejumlah hasil penelitian mengenai media permainan ular tangga telah dilakukan oleh Aprilia Wahyu Mardhani (2017) yang mengembangkan permainan ular tangga akuntansi untuk meningkatkan motivasi belajar kompetensi mengelola kartu piutang, Nurfadillah Salam (2017) pada materi saraf, Endah Rosela (2016) mengembangkan permainan ular tangga untuk meningkatkan motivasi dan hasil belajar pada materi peredaran darah manusia, Elan Jaelani, dkk.,(2016) yang menerapkan media ular tangga bercerita untuk meningkatkan keterampilan berpikir kritis pada konsep pencemaran lingkungan, Rifki Afandi (2015) mengembangkan media untuk meningkatkan motivasi belajar siswa dan hasil belajar ips di sekolah dasar, Purwaningsih dan Siti Maesaroh (2016) mengembangkan media berbasis pendidikan karakter untuk meningkatkan prestasi belajar.

Adanya permasalahan dalam pembelajarn biologi berdasarkan hasil observasi dan wawancara yang telah dilakukan serta adanya solusi yang sudah diteliti oleh

42 Inayatus Solekhah et al. - Pengembangan Media Pembelajaran Ular Tangga Bercerita Berbasis Pendidikan Karakter Untuk Meningkatkan Kemampuan Berpikir Kritis Siswa Kelas X Pada Materi Ekosistem 
beberapa peneliti sebelumnya, sehingga pembelajaran menggunakan media permainan ular tangga bercerita pada pembelajaran biologi dapat menjadi peluang pemecahan masalah. Materi ekosistem merupakan salah satu materi sesuai untuk digunakan objek pengembangan media karena materi ekosistem berkaitan langsung dengan lingkungan sekitar, sehingga memudahkan siswa untuk menganalisis lebih lanjut. Pengembangan permainan ular tangga ekosistem dapat dilengkapi dengan buku pegangan, media ular tangga menerapkan nilai karakter: peduli lingkungan, berpikir kritis, kreatif, dan peduli sosial. Tujuan penelitian yang akan dilakukan adalah mengembangkan media ular tangga bercerita berbasis pendidikan karakter untuk meningkatkan kemampuan berpikir kritis siswa kelas X pada materi ekosistem di MA Hidayatul Mubtadi'in.

\section{METODE PENELITIAN}

Jenis penelitian yang dilakukan adalah Research and Development (R\&D) yang bertujuan untuk menghasilkan/mengembangkan produk tertentu, sekaligus untuk menguji keefektifan produk tersebut dalam proses pembelajaran. Model pengembangan dalam penelitian ini yaitu: ADDIE (Analysis, Design, Develop, Implementation, Evaluation) atau analisis, desain/perancangan, pengembangan, Implementasi/eksekusi, dan evaluasi (Paidi, 2012: 80).

Produk yang telah dikembangkan selanjutnya di uji sekala kecil dengan subjek 10 orang siswa masing-masing kelas 5 orang pada materi ekosistem. Uji coba selanjutnya dilakukan dengan kuasi eksperimen pada 2 kelas dengan ketentuan kelas kontrol (X MIA 2) dengan jumlah 21 orang siswa dan kelas ekperimen (X MIA 1) dengan 25 orang siswa. Teknik analisis data yang digunakan untuk mengetahui kemampuan berpikir kritis dengan tes essay 10 butir soal pada pre test dan post test kelas eksperimen dan kelas kontrol, sedangkan untuk mengetahui tanggapan peserta didik setelah menggunakan media ular tangga bercerita dilakukan dengan sebaran angket. Wawancara tidak terstruktur digunakan untuk menganalisis kebutuhan siswa MA Hidayatul Mubtadiin.

Uji validitas produk ular tangga bercerita dilakukan oleh ahli materi ekosistem dan ahli media pembelajaran. Uji validitas dilakuakn dengan skala likert, selanjutnya hasil dihitung dengan rumus persentase dan hasilnya dikategorikan sesuai dengan Tabel 1 Berikut.

Tabel 1 Skala Kelayakan Produk

\begin{tabular}{|c|c|}
\hline Presentase & Kriteria \\
\hline $0 \%-20 \%$ & Sangat kurang layak \\
\hline $21 \%-40 \%$ & Kurang layak \\
\hline $41 \%-60 \%$ & Cukup layak \\
\hline $61 \%-80 \%$ & Layak \\
\hline $81 \%-100 \%$ & Sangat layak \\
\hline
\end{tabular}

(Sumber: Wahyu, 2017:90) 
Analisis data angket peserta didik dilakukan dengan analisis statistik diskriptif, dengan mengkonversi jawaban "ya" menjadi 1 dan "tidak" menjadi 0 pada pertanyaan positif, sedangkan pada pertanyaan negative "ya" bernilai 0 dan "tidak" bernilai 1 . Data angket tersebut dianalisis dengan rumus persentase dan hasilnya dikategorikan sesuai dengan Tabel 2 Berikut.

Tabel 2 Tingkat respon siswa terhadap produk

\begin{tabular}{|c|c|}
\hline Presentase & Kriteria \\
\hline $81 \%-100 \%$ & Sangat menarik \\
\hline $61 \%-80 \%$ & Menarik \\
\hline $41 \%-60 \%$ & Cukup menarik \\
\hline $21 \%-40 \%$ & Kurang menarik \\
\hline $0 \%-20 \%$ & Sangat tidak menarik \\
\hline
\end{tabular}

(Sumber: Fitriana, 2018: 55)

Teknik analisis kemampuan berpikir kritis dilakukan dengan uji awal (uji validitas, reabilitas, daya pembeda, dan tingkat kesuran soal) data yang memenuhi kriteria tersebut dijadikan sebagai soal pre test dan post test. Uji lanjutan dilakukan independent sample t-test untuk mengetahui perbedaan rata-rata pada kelas kontrol dan kelas eksperimen, serta uji n-gain untuk mengetahui kefektivan penggunaan media ular tangga bercerita. Peningkatan kemampuan berpikir kritis siswa dilakukan dengan uji $\mathrm{N}$-gain dengan kategori tingkat perolehan sebagai berikut.

Tabel 3. Tingkat Perolehan Indeks Gain

\begin{tabular}{|c|c|}
\hline Presentase & Kriteria \\
\hline $\mathrm{g}>70$ & Tinggi \\
\hline $30 \leq \mathrm{g} \leq 70$ & Sedang \\
\hline $\mathrm{g}<30$ & Rendah \\
\hline
\end{tabular}

(Sumber: Rosidiana ET AL. 2015:52)

\section{HASIL PENELITIAN DAN PEMBAHASAN}

Penelitian ini menghasilkan produk berupa media ular tangga bercerita berbasis pendidikan karakter untuk meningkatkan kemampuan berpikir kritis, dengan model pengembangan ADDIE. Adapun tahap penelitian ini yaitu:

\section{Analisis}

Tahap analisis dibedakan menjadi 2 yaitu: analisis tugas dan analisis kebutuhan. Analisis kebutuhan dan analisis tugas didasarkan pada hasil wawancara dan sebaran angket terkait penggunaan media dan metode pembelajaran yang terkesan monoton dan kurang menarik, sehingga menurunkan tingkat antusias peserta didik dalam proses pembelajaran yang berakibat pada menurunnya kemampuan berpikir kritis siswa. Berdasarkan wawancara dan sebaran angket yang dilakukan diketahui media pembelajaran yang sering digunakan adalah: power point dengan persentase $40 \%$, video dengan persentase $10 \%$ dan buku ajar (LKS/buku paket) dengan persentase $50 \%$. Hasil tersebut menunjukkan media pembelajaran yang 
digunakan tidak sesuai dengan karakteristik peserta didik. Hal ini dikarenakan peserta didik menyukai media pembelajaran game edukatif dengan presentase $80 \%$. Oleh karenanya, diperlukan suatu media pembelajaran yang menyenangkan yang menuntut siswa untuk belajar mandiri dan bertanggung jawab melalui media ular tangga bercerita.

Media ular tangga yang dikembangkan bertujuan meningkatkan partisipasi siswa dalam pembelajaran, menciptakan suasana pembelajaran yang menyenangkan, meningkatkan analisis siswa dalam menghadapi masalah, serta menumbuhkan nilai karakter. Hal ini selaras dengan fungsi dan peran media yang digunakan untuk membangkitkan keinginan, minat, motivasi, stimulus kegiatan belajar, proses pembelajaran lebih interaktif dan membawa pengaruh bagi psikologi peserta didik (Arsyad, 2011: 15).

\section{Desain}

Berdasarkan hasil analisis kebutuhan tersebut, dikembangkanlah media ular tangga bercerita berbasis pendidikan karakter. Media ini di desain dengan menarik dan dilengkapi dengan buku pegangan, peraturan permainan, kartu soal dan kartu kunci, papan permainan, dan kotak penyimpanan media. Peraturan permainan media ini sama dengan ular tangga secara umumnya, perbedaannya pada pemain yang tidak mampu menjawab soal tidak diperbolehkan berpindah petak, hal tersebut berlaku pada saat memperoleh tangga, dan diharuskan turun ketika pion berada di ekor ular serta tidak mampu menjawab pertanyaan.

Desain papan ular tangga bercerita menggunakan kombinasi antara gambar tentang materi ekosistem dan nilai karakter (peduli lingkungan, berpikir kritis, peduli social, kreatif dan komunikatif). Gambar dan nilai karakter tersebut menjadi representasi pertanyaan pada kartu soal. Papan ular tangga berbentuk persegi yang terdiri dari 49 kotak yang ditunjuk pada gambar 1. Kartu soal di desain dengan level pertanyaan kognitif MOTS dan HOTS, kartu soal dan kartu kunci dapat dilihat pada gambar 2 dan 3 .

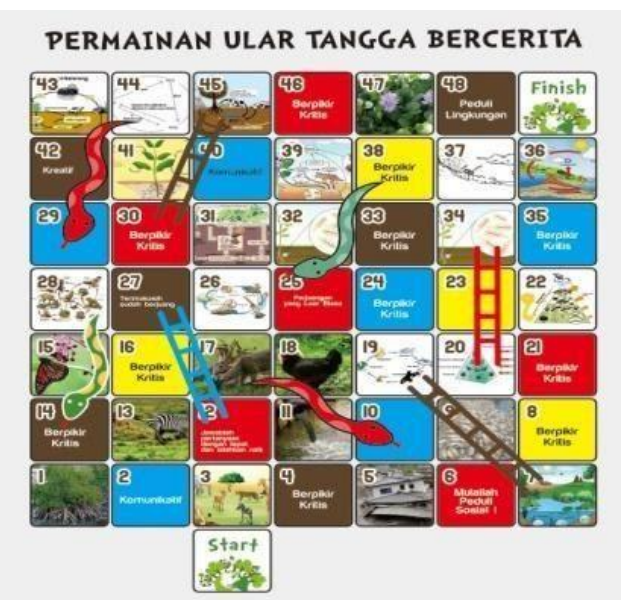

Gambar 1. Papan Ular Tangga Bercerita

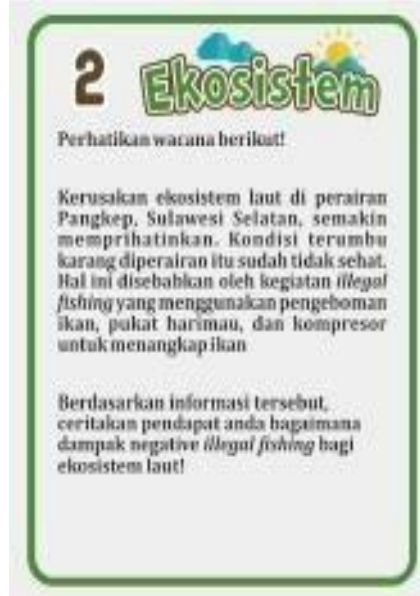

Gambar 2. Kartu Soal

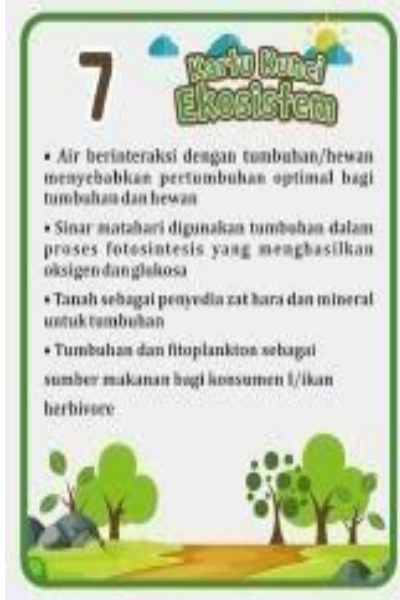

Gambar 3. Kartu Kunci

Inayatus Solekhah et al. - Pengembangan Media Pembelajaran Ular Tangga Bercerita Berbasis Pendidikan Karakter Untuk Meningkatkan Kemampuan Berpikir Kritis Siswa 
Kelengkapan lain dari media ini yaitu: buku pegangan yang merupakan rangkuman materi tentang pertanyaan pada kartu soal dapat dilihat pada gambar 4 . Peraturan permainan yang digunakan sebagai pedoman dalam permainan dapat dilihat pada gambar 5. Dadu dan pion merupakan bagian dari kelengkapan media ini, dadu digunakan sebagai penentu langkah pemain dalam permainan dan pion sebagai pemain dalam permainan, pada pengembangan media ini terdapat 1 dadu dan 3-5 pion dapat dilihat pada gambar 6 dan kotak penyimpanan pada gambar 7 .

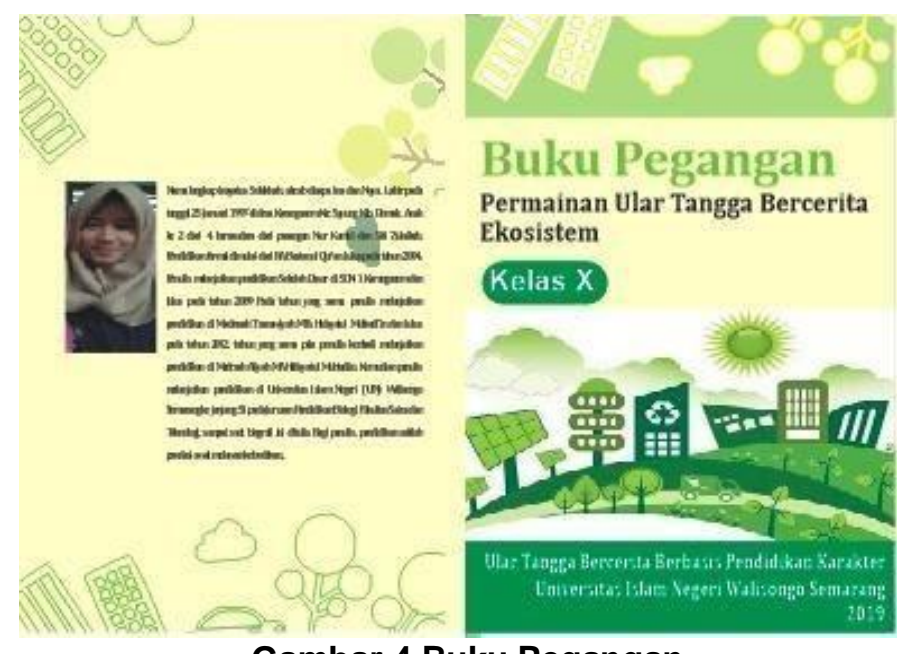

Gambar 4 Buku Pegangan

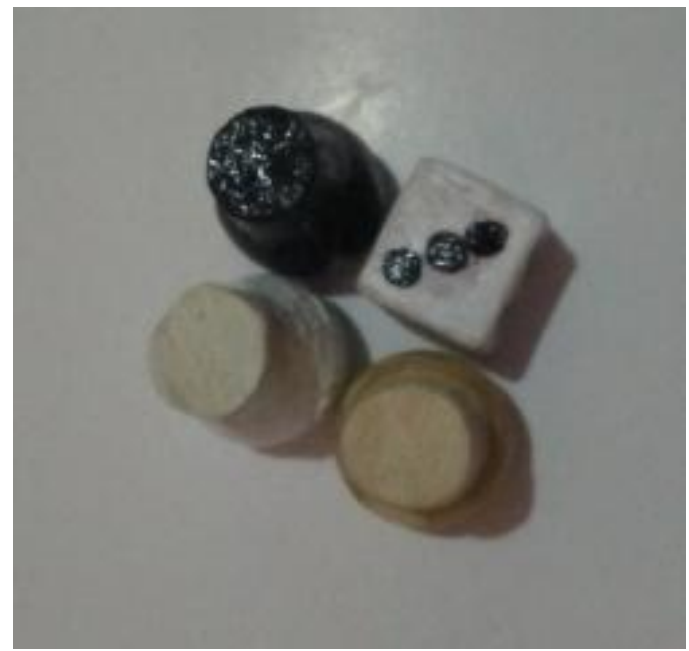

Gambar 6 Dadu dan Pion

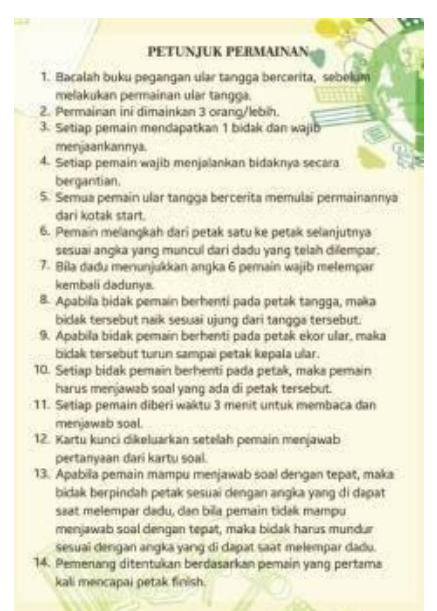

Gambar 5 Peraturan Permainan

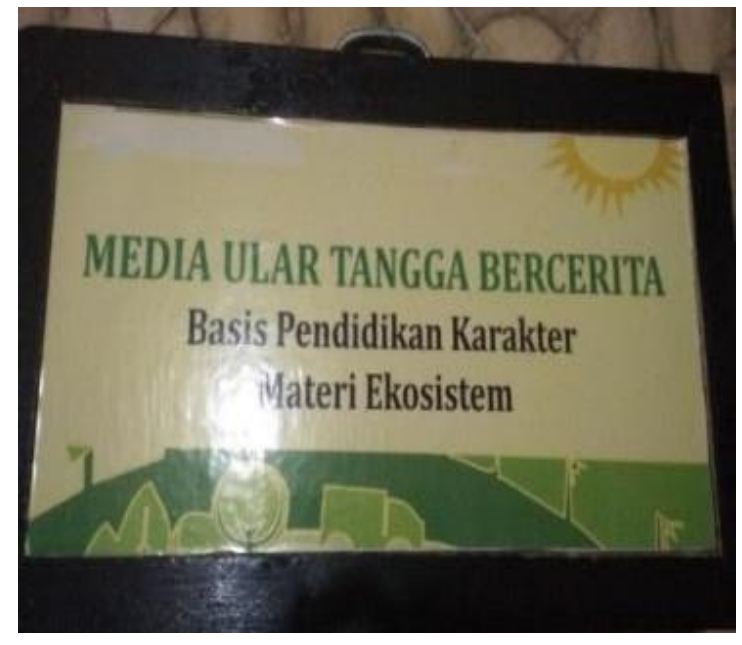

Gambar 7 Kotak Penyimpanan

\section{Develop dan Implementasi}

Tahap ini bertujuan untuk mengetahui layak tidaknya pengembangan produk ular tangga bercerita diterapkan kepada peserta didik. Validasi ini dilakukan oleh ahli materi, ahli media, dan praktisi pendidikan. Adapun hasil validasi produk sebagai berikut. 


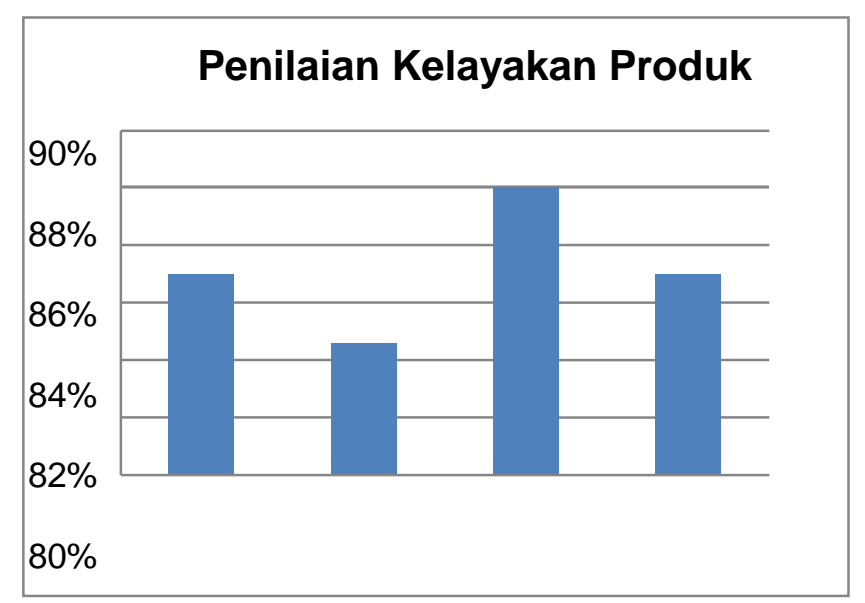

Gambar 8. Penilaian kelayakan produk

Gambar 8 menunjukkan persentase penilaian ahli materi sebesar $85 \%$ dengan kategori sangat layak. Penilaian ahli materi meliputi substansi materi dan pertanyaan yang terdapat dalam kartu soal. Adapun saran terkait perbaikan produk yaitu: kesalahan penulisan/typo, penambahan penjelasan pada daur karbon, pemilihan gambar, MOTS dan HOTS yang sinkron dengan pernyataan soal, dan kunci jawaban yang kurang sesuai dengan pertanyaan.

Uji validasi ahli media terdapat beberapa catatan antara lain: dadu dan pion diperbesar, ukuran ular tangga diperbesar, peraturan permainan yang dipisah dari buku pegangan, penambahan biografi pada buku pegangan, dan perlunya kotak penyimpanan media agar mudah dan praktis dibawa. Hasil penilaian ahli media menunjukkan media ular tangga sangat layak digunakan dengan persentase $82,6 \%$.

Selanjutnya, penilaian produk oleh guru biologi bertujuan untuk mengetahui kelayakan dan kemanfaatan produk melalui penerapan langsung. Berdasarkan penilaian, menunjukkan persentase $88 \%$ yang berarti media sangat layak untuk diterapkan. Hasil penilaian tersebut tidak mendapatkan catatan perbaikan, karena sesuai dengan KD dan tampilannya menarik, dan mudah untuk diterapkan.

Tahap selanjutnya yaitu dilakukan penerapan media. Penerapan ini dilakukan melalui 2 tahap: uji skala kecil dan uji lapangan/skala besar. Uji skala kecil dilakukan pada 10 orang siswa, 5 orang dari kelas X MIA 1 dan 5 orang dari kelas X MIA 2. Uji skala kecil bertujuan untuk memperoleh masukan dan saran dari peserta didik setelah menggunakan permainan ular tangga. Hasil rata-rata uji skala kecil dari 10 siswa dengan 10 pertanyaan menunjukkan persentase $85 \%$. Penilaian produk ini merujuk pada pendapat Walker \& Hess (1984), bahwa kriteria me-review media pembelajaran didasarkan pada aspek kualitas isi dan tujuan, terdiri dari: ketepatan, kelengkapan, keseimbangan, kesesuaian dengan situasi siswa, minat dan perhatian; aspek kualitas pembelajaran yaitu: memberikan kesempatan belajar, memberikan bantuan belajar, fleksibel, kualitas sosial interaksi pembelajarannya, dan dapat memberikan dampak untuk siswa: serta pada aspek kualitas teknis terdiri dari: keterbacaan, mudah digunakan, kualitas tampilan, kualitas penangkapan jawaban (Cecep \& Sutjipto, 2011: 145).

Inayatus Solekhah et al. - Pengembangan Media Pembelajaran Ular Tangga Bercerita Berbasis Pendidikan Karakter Untuk Meningkatkan Kemampuan Berpikir Kritis Siswa 


\section{Evaluasi}

Tahap ini berupa analisis data keefektifan pre-test dan post-test yang meliputi melalui uji normalitas, uji homogenitas, uji independent sampel $t$-test (uji T), dan uji $\mathrm{N}$ gain score. Nilai post-test kelas eksperimen dan kelas kontrol digunakan untuk mengetahui indikator kemampuan berpikir kritis siswa. Adapun indikator tersebut meliputi: interpretasi, infers, analisis, penjelasan, dan evaluasi.

1. Peningkatan kemampuan berpikir kritis

Uji lapangan/uji skala besar bertujuan untuk mengetahui tingkah efektivitas dari penggunaan media ular tangga bercerita untuk meningkatkan kemampuan berpikir kritis. Adapun hasil kemampuan berpikir kritis siswa kelas eksperimen dan kelas kontrol pada pre-test dan post-test, seperti pada gambar 9.

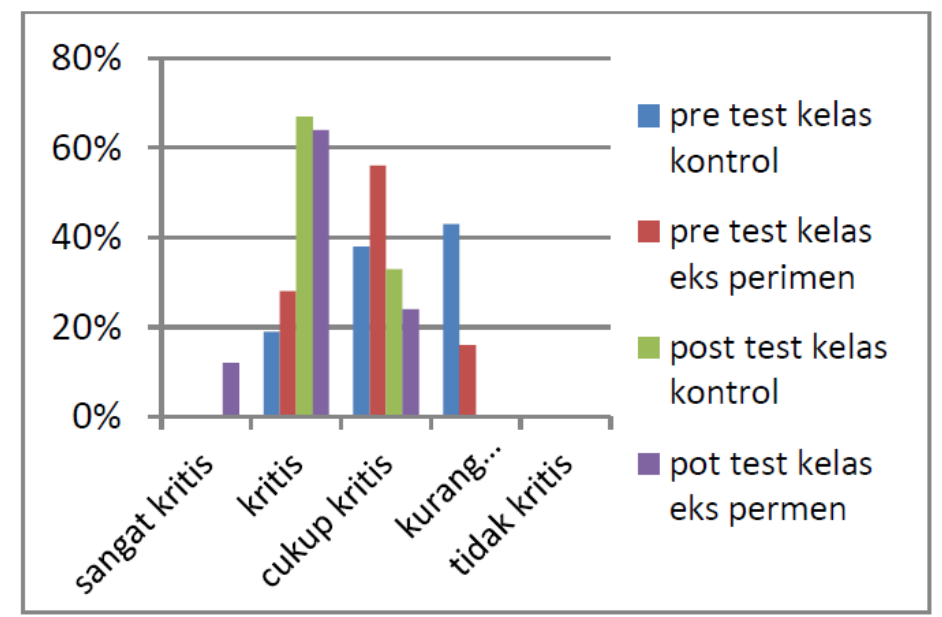

Gambar 9. Perbandingan kemampuan berpikir kritis siswa

Data tersebut menunjukkan nilai post-test kelas eksperimen lebih baik dari pada nilai post-test kelas kontrol yakni: sangat kritis $12 \%$, kritis $64 \%$ dan $24 \%$ cukup kritis, sedangkan nilai post-test kelas kontrol $67 \%$ kritis dan $33 \%$ cukup kritis. Penilaian pre-test kelas eksperimen $28 \%$ kritis, $56 \%$ cukup kritis, dan $16 \%$ kurang kritis, sedangkan kelas kontrol 19\% kritis, 38\% cukup kritis, dan $43 \%$ kurang kritis. Hasil tersebut dijabarkan dalam bentuk indikator sebagaimana gambar 10 .

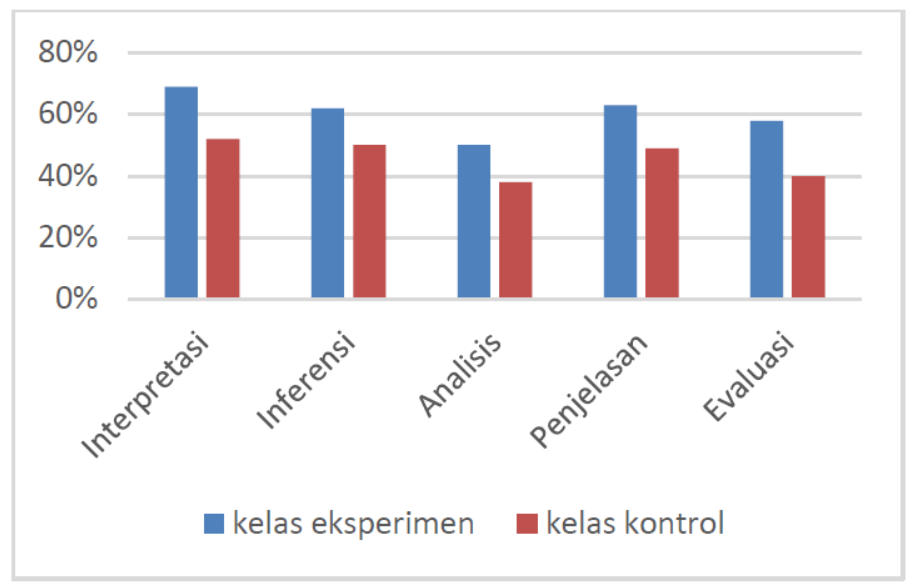

Gambar 10. Perbandingan indikator kemampuan berpikir kritis 
Gambar tersebut menunjukkan nilai kemampuan berpikir kritis kelas eksperimen lebih tiggi dibandingkan kelas kontrol. Hasil nilai rata-rata aspek interpretasi pada kelas eksperimen $69 \%$ dan kelas kontrol 52\%, aspek inferensi dengan persentase kelas eksperimen $62 \%$ dan kelas kontrol $50 \%$, kelas eksperimen dan kelas kontrol aspek analisis $50 \%$ dan $38 \%$, aspek penjelasan dengan persentase $63 \%$ dan $49 \%$ dan aspek evaluasi $58 \%$ dan $43 \%$.

Menurut Uno dalam Elan,dkk., (2016:12), mengajukan pertanyaan adalah stimulus efektif yang mendorong kemampuan berpikir. Keterampilan bertanya/interpretasi bertujuan untuk meningkatkan kemampuan berpikir siswa dari tingkat rendah ke tingkat yang lebih tinggi. Hal ini di perkuat dengan pendapat Hustandi \& Bambang (2011: 1), bahwa pembelajaran yang efektif mampu meningkatkan interaksi positif antara guru dengan peserta didik dan memberikan pengalaman nyata untuk memperoleh informasi, sehingga dari aktivitas tersebut mampu meningkatkan pemahaman dan kemampuan berpikir siswa.

\section{Analisis Perbedaan Peningkatan Kemampuan Berpikir Kritis}

Analisis ini diawali dengan uji normalitas dan homogenitas. Hasil uji normalitas diketahui data pre-test dan post test kelas eksperimen dan kelas kontrol berdistribusi normal, dimana nilai signifikasi pada Shapiro Wilk> 0.05 sedangkan pada uji homogenitas data memiliki varian homogen dengan nilai signifikai $0.634>$ 0.05 .

Uji Hipotesis dilakukan dengan uji t-test, jenis independent sample t-test yang bertujuan untuk mengetahui perbedaan rata-rata kelas kontrol dan kelas eksperimen, dengan nilai rata-rata post test kelas eksperimen 76 dan nilai rata- rata post test kelas kontrol 66.01 untuk lebih jelasnya dapat dilihat pada gambar 4.35 . Berdasarkan output independent samples t-test pada bagian equal variance assumed diketahui nilai sig 2 tailed $0.000<0.05$, dengan thitung $=3.891$ dan ttabel $=2.01537$, dimana thitung $>\mathrm{t}$ tabel maka, Ha diterima dan Ho ditolak, sehingga terdapat perbedaan yang signifikan antara kelas eksperimen dan kelas kontrol.

Uji $n$-gain digunakan untuk menguji efektivitas media ular tangga bercerita. Berdasarkan hasil pengolahan data didapat nilai rata-rata kelas eksperimen 43.48 termasuk dalam kategori sedang, dengan nilai minimal 12.5 dan nilai maksimal 66.67, sedangkan nilai rata-rata kelas kontrol 35.32 termasuk dalam kategori rendah, dengan nilai minimal 20.83 dan nilai maksimal 53.85 sehingga disimpulkan penggunaan media ular tangga bercerita efektif untuk meningkatkan kemampuan berpikir kritis. Beberapa penelitian yang relevan, seperti Elan (2016), menunjukkan hasil penerapan media ular tangga untuk meningkatkan kemampuan berpikir kritis lebih tinggi peningkatannya dibandingkan media konvensional. 


\section{SIMPULAN DAN SARAN}

Simpulan dari penelitian pengembangan ular tangga bercerita berbasis pendidikan karakter untuk meningkatkan kemampuan berpikir sisswa kelas $X$ pada materi ekosistem MA Hidayatul Mubtadi'in sebagai berikut.

Media ular tangga bercerita dikembangkan dengan model pengembangan ADDIE, aplikasi yang digunakan diantaranya corel draw x4 dan microsoft word 2008. Subtansi petak media ular tangga mencakup 4 dari 15 nilai karakter yakni: komunikatif, peduli lingkungan, peduli sosial, dan kreatif, sedangkan berpikir kritis muncul dari stimulus pertanyaan dengan MOTS dan HOTS. Media ini dilengkapi dengan papan media, kartu soal, kartu kunci, buku pegangan, petunjuk permainan, dan kotak permainan.

Hasil validasi ahli menyatakan bahwa media layak digunakan, dengan rincian persentase validitas ahlii materi $85 \%$, ahli media $82,6 \%$, dan praktisi pendidikan sebesar $88 \%$.

Hasil uji efektivitas media dalam meningkatkan kemampun berpikir kritis siswa kelas X pada materi ekosistem MA Hidayatul Mubtadi'in. hasil uji pre-test dan post-test kelas eksperimen dan kontrol menunjukkkan nilai thitung $=3.891$ dan ttabel $=2.0154$, sehingga thitung $>$ ttabel sehingga dapat disimpulkan terdapat perbedaan hasil posttest kelas ekperimen dengan kelas kontrol. Hasil uji N-gain juga menunjukkan nilai rata-rata kelas eksperimen dengan presentase 43.48 yang berarti sedang, sehingga disimpulkan bahwa penggunaan media ular tangga bercerita berbasis pendidikan karakter terbukti efektif untuk meningkatkan kemampuan berpikir kritis siswa kelas $X$ pada materi ekosistem MA Hidayatul Mubtadi'i

\section{UCAPAN TERIMA KASIH}

Terima kasih kepada Ketua Jurusan Pendidikan Biologi UIN Walisongo Semarang. Terima kasih juga kepada segenap yang terlibat dalam penelitian ini, yakni guru dan siswa kelas X MA Hidayatul Mubtadi'i , para validator, pihak lain yang turut membantu sehingga penelitian ini dapat diselesaikan sesuai harapan.

\section{RUJUKAN}

Afandi, Rifki. (2015).Pengembangan Media Pembelajaran Permainan Ular Tangga Untuk Meningkatkan Motivasi Belajar Siswa dan Hasil Belajar IPS di Sekolah Dasar. JINoP (Jurnal Inovasi Pembelajaran). Vol. 1 nomor. , Mei 2015. Hal. 7789

Arsyad,Azhar. (2003). Media Pembelajaran. Jakarta: PT Raja Grafindo Persada Departemen Pendidikan Nasional. 2003. Undang-undang No. 20 Tahun 2003 Tentang Sistem Pendidikan Nasional. Jakarta: Depdiknas

Elan Jaelani, Wahidin, \& Evirofiati. (2016). Penerapan Media Ular Tangga Bercerita Untuk Meningkatkan Keterampilan Berpikir Kritis Siswa Kelas VII Pada Konsep

Pencemaran Lingkungan Di Mts Al-Muatawally Kuningan. jurnal Sains dan Pendidikan Sains Vol. 5 No. 1. Hal: 25-38,

Hariyanti, Sri. (2017). Pendidikan Karakter Dalam Kurikulum 2013. FKIP-UTM Paidi. 2012. Metodelogi Penelitian Pendidikan Biologi. Yogyakarta: UNY Press 
Peraturan Menteri Pendidikan Dan Kebudayaan Nomor 20 Tahun 2018 Tentang Penguatan Pendidikan Karakter Pada Satuan Pendidikan Formal

Perpres Nomor 87 Tahun 2017 Tentang Penguatan Pendidikan Karakter

Prayoga, Zumisa Nudia. (2013).Kemampuan Berpikir Kritis Siswa Pada Pembelajaran Materi Pengelolaan Lingkungan Dengan Pendekatan Keterampilan Proses Sains.Skripsi.Jurusan Biologi Fakultas Matematika Dan IImu Pengetahuan Alam Universitas Negeri Semarang

Purwaningsih dan Maisaroh Siti. (2016). Pengembangan Media Pembelajaran Ular Tangga Berbasis Pendidikan Karakter Untuk Meningkatkan Prestasi Belajar IPS Kelas IV SD Donotirto Tahun Ajaran 2015/2016.Universitas PGRI Yogyakarta

Ramli, M. (2015). Media Pembelajaran Dalam Perspektif Al-Qur'an dan Hadits. Ittihad Jurnal Kopertais Wilayah XI Kalimantan Vol. 13

Rosela, Endah. (2016). Penggunaan Media Edukasi Ular Tangga Untuk Meningkatkan Motivasi dan hasil Belajar Peserta Didik Kelas VIII SMP Negeri 2 Mlati Sleman Pada Materi Peredaran Darah Manusia. Pendidikan Biologi JUrusan Pendidikan Matematika dan IImu Pengetahuan Alam, Fakultas Keguruan dan IImu Pendidikan Universitas Sanata Dharma Yogyakarta

Salam, Nurfadillah. (2017). Pengembangan Media Pembelajaran Permainan Ular Tangga Pada Materi Sistem Saraf Di Kelas XI MA Madani Alauddin Paopao (skripsi). Jurusan Pendidikan Biologi Fakultas Tarbiyah Dan Keguruan Universitas Islam Negeri (UIN) Alauddin Makassar

Uno, Hamzah B. (2016). Assessment Pembelajaran. Jakarta: Bumi Aksara

Wahyu Lestari Atsni. (2017). Pengembangan Modul Pembelajaran Biologi Berbasis Kearifan Lokal Di Kawasan Wisata Goa Kreo Pada Materi Ekosistem Kelas X SMA Negeri 16 Semarang. Fakultas Sains Dan Teknologi Universitas Islam Negeri Walisongo Semarang

Wahyu, Aprilia Mardhani. (2017). Pengembangan Media Pembelajaran Permainan Ular Tangga Akuntansi Untuk Meningkatkan Motivasi Belajar Kompetensi Mengelola Kartu Piutang Kelas XI Keuangan SMK Muhammadiyah 1 Prambanan Klaten Tahun Ajaran 2016/2017. Program Studi Pendidikan Akuntansi Jurusan Pendidikan Akuntansi Fakultas Ekonomi Universitas Negeri Yogyakarta

Wartini, Atik \& Muhammad Askar. (2015). Al-Quran Dan Pemanfaatan Permainan Edukatif Pada Anak Usia Dini. Jurnal Al-Afkar. Vol. III, No. 1

Zubaidah, Siti. (2010). Berpikir Kritis: Kemampuan Berpikir Tingkat Tinggi yang Dapat Dikembangkan melalui Pembelajaran Sains. Biologi FMIPA Universitas Negeri Malang

Hanum, Ikhwatul. (2019). Wawancara Guru Biologi MA Hidayatul Mubtadiin. pada 21 Desember 2019 pukul 10.00 WIB 